\title{
CORRECTION
}

\section{Correction to: A metagenomic study of the rumen virome in domestic caprids}

\author{
Samuel Namonyo ${ }^{1,2} \cdot$ Maina Wagacha $^{1} \cdot$ Solomon Maina ${ }^{2} \cdot$ Lillian Wambua $^{1,4} \cdot$ Morris Agaba $^{2,3}$
}

Published online: 10 October 2018

C) Springer-Verlag GmbH Austria, part of Springer Nature 2018

\section{Correction to: Archives of Virology}

$$
\text { https://doi.org/10.1007/s00705-018-4022-4 }
$$

Unfortunately, the original article was online published with error in the results section. The error is correction by this erratum.

The last line of the "Results" section should read as:

Sequences bearing similarities with the Tectiviridae and Marseillevirus were detected in the sheep but not the goat (Table 2).

Samuel Namonyo

namonyosamuel@gmail.com

1 The University of Nairobi, Nairobi, Kenya

2 BecA-ILRI Hub, Nairobi, Kenya

3 The Nelson Mandela African Institute of Science and Technology, Arusha, Tanzania

4 International Centre for Insect Physiology and Ecology, Nairobi, Kenya 